\title{
Study The Link Between Accounting and Taxation Practice in Vietnam
}

\author{
Anh Tuan Nguyen*1, Tung Dao Nguyen**, Hien Thu Nguyen*2 \\ * Faculty of Accounting, Academy of Finance, Hanoi, Vietnam \\ **Academy of Finance, Hanoi, Vietnam \\ 1) Corresponding author: nguyentuananh@hvtc.edu.vn \\ 2). hiennt@hvtc.edu.vn
}

\begin{abstract}
The objective of the study is to analyze and evaluate the link between accounting and taxation through the synthesis of domestic and foreign studies, combined with analysis of specific regulations in Vietnam. The study identifies 11 contents that have an interference between accounting and tax to conduct surveys in enterprises. After analyzing and explaining the survey results, the researcher decides to choose 06 representative contents in choosing the rules according to the level (low, medium, high) to conduct the analysis. The research results show that the tendency to choose to use accounting rules higher than tax rules and the link between accounting and taxation in Vietnam is moving to become more independent. At the same time, large enterprises will prefer the use of accounting rules over tax rules and vice versa for small and medium enterprises. Through the results of this research, policy makers can identify the position of the link between accounting and taxation, and then make decisions to adjust the relationship between accounting and taxation appropriately with the integration and development of Vietnam's economy.
\end{abstract}

Keywords: Accounting, Tax, Link, Rules, Content.

\section{How to Cite:}

Nguyen, A. T., Nguyen, T. D., and Nguyen, H. T. (2021). Study the link between accounting and taxation practice in Vietnam. Journal of Accounting and Taxation, 1(1). 12 - 24. DOI. https://doi.org/10.47747/jat.v1i1.434

\section{Introduction}

The relationship between accounting and taxation is a topic attracting more and more attention of researchers around the world through a lot of discussions, articles and analysis which have been done to understand their influences and existing relationships. Solving the relationship between the accounting system and tax regulations is not only an important job of tax authorities and businesses, but also influences the economy development. The accounting system and tax laws are two important policy systems of a country. The purpose of accounting is generally believed to provide interested parties with information related to management, control, and decision-making. The relationship between accounting and taxation develops in different stages in different countries. In Vietnam, in the period of centrally planned economy (before 1986), taxation and accounting followed the Soviet model, which served the common purposes of the State. Since 1986, Vietnam's economy has transformed to a socialist-oriented market economy, the accounting and tax systems have undergone many 
changes and have been greatly reformed as well. Until now, accounting and taxation in Vietnam have made new developments when the separation has increased. However, this separation is essential for the developments. In order to assess the separation between accounting and taxation, this study focuses on analyzing the relationship between accounting and taxation in Vietnam in the current period through 06 connection contents, from which the research shows the selection trend of using accounting and tax rules. What is the relationship between accounting and taxation in Vietnam? Then researchers have to base on the results to bring about conclusion.

\section{Literature Review}

\subsection{Overview of The Research on The Relationship Between Accounting and Taxation}

There have been many studies conducted to understand the relationship between accounting and taxation in many countries in the world. It is generally assumed that this relationship develops differently between countries, periods and historical contexts of each country. There are two fundamentally different relationships between accounting and taxation which are "independent" and "dependent" ones (Hoogendoorn, 1996). Although this relationship is dependent or independent, the relationship is still considered to be the same in general. When it is considered to be independent, it does not mean that there is no intersection between accounting and taxation, but just a weak relationship. Accounting principles and tax regulations are two concepts developed and applied by two different bodies, so the principles are often not identical due to different purposes (Duhanxhiu \& Kapllani, 2012), which leads to different regulations. However, the relationship between accounting and taxation is never completely independent, they always govern each other in various manners, tax liabilities are based on accounting principles (Alley \& James, 2005) and accounting is affected by taxation (Fekete et al., 2012). Therefore, it can be asserted that there is a real dependence of accounting on taxation and vice versa. The relationship between accounting and taxation can take the following forms: the accounting principles are consistent with tax regulations, the degree of relationship and the similarity between the two systems.

In fact, the relationship between accounting and taxation is much more complicated due to the difference in perception or approach. The relationship between accounting and taxation is considered to be a significant improvement, since taxation and accounting govern each other (Shaviro, 2009) and there is always a relationship between them (Cuzdriorean, 2012). The relationship degree between accounting and taxation can vary depending on countries (due to differences in accounting between countries) as well as the size of businesses.

Lamb et al. (1998) developed a method to assess and classify the relationship between accounting and taxation in countries into five cases, including: case I (disconnection), in which the accounting and tax rules are different and are applied differently depending on mentioned types (accounting rules for accounting profits and tax rules for taxable profits); case II (identity), in which accounting and taxation must follow the same principles; case III (accounting leads), in which accounting principles are used in both determining accounting profits and taxes (accounting leads), accounting principles are more specific than tax rules; case IV (tax leads), in which accounting profits are determined according to accounting and tax principles, and tax profits are determined according to tax principles, tax principles are more specific than accounting principles; Finally, case V (tax dominates), in which tax principles are used to determine taxable income and accounting profits (Diagram 1). 
Case 1. Disconnection

Case 2. Identity

Case 3. Accounting leads

Case 4. Tax leads

Case 5. Tax dominates

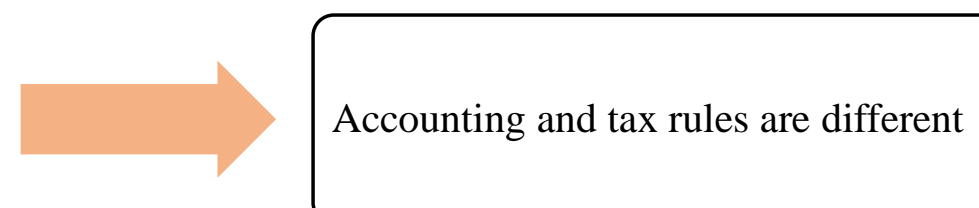

Accounting and tax rules are similar

Accounting and tax rules are similar

A financial reporting rule or option is followed for financial reporting purpose, and also for tax purposes

A tax rule or option is followed for tax purposes, and also for financial reporting

A tax rule or option is followed for tax and financial reporting purposes instead of a conflicting financial reporting rule

Diagram 1. The research model of the relationship between accounting and taxation

Source: Author's projection based on study conducted by Lamb et al. (1998)

\subsection{The Relationship Between Accounting and Taxation}

\subsubsection{The basis for determining the relationship between accounting and taxation}

Lamb et al. (1998) based on 15 contents of the relationship between accounting and taxation (the record and valuation of fixed assets; financial leases and operations; provisions, assets and contingent liabilities; allowances; research and development costs; inventory valuation; long-term contracts; interest expenses; foreign currency transactions; non-consolidation purchased goodwill; pensions; changes in accounting policies and serious mistakes; scope of accounting; fines, charitable donations, entertainment expenses) in order to assess the taxation-accounting relationship which is classified into five cases (Diagram 1). When analyzing the relationship between accounting and taxation for listed Spanish companies, Gallego (2004) identified the following contents, including: income tax expenses, welfare regime, pension provisions, accelerated depreciation, or reinvestment tax exemptions which are differences between accounting and tax profits. Continuing to develop the research method of Lamb et al. (1998), Nobes \& Schwencke (2006) built a model to develop and evaluate the relationship degree between accounting and taxation in Norway and proposed to add more principles on fixed asset devaluation and financial asset measurement, which was different for the research of Lamb et al. (1998). 
In Vietnam, based on the method of Lamb et al. (1998), Nobes \& Schwencke (2006), Nguyen Cong Phuong (2010) conducted a research on the relationship between accounting and taxation in Vietnam and adjusted the contents used to assess the relationship between accounting and taxation in order to conform to specific regulations in Vietnam, including: contingent liabilities and liability provisions; consolidation purchased goodwill; revenue recognition; accrual expenses, amortization expenses, the rate of provisions; and expenses for marketing, advertising, promotions, meetings. Based on the above studies, this study has determined 17 typical overlapping contents between accounting and taxation, including: (1) fixed asset measurement; (2) fixed assets depreciation; (3) Classification of leases; (4) Grants and subsidies; (5) Contingent liability and provision; (6) Research and development expenses; (7) Inventory valuation; (8) Interest expenses; (9) Foreign currency transactions; (10) Consolidation purchased goodwill; (11) Government grants and subsidies; (12) Changes in accounting policies, accounting estimation and serious mistakes; (13) The scope of accounting entity and taxpayers; (14) Fines, compensation, charitable donations, entertainment expenses; (15) Revenue recognition; (16) Revenue recognition from financial operations; (17) Accrued expenses, amortized expenses, provisioning rate.

\subsubsection{The relationship between accounting and taxation in Vietnam}

On the basis of the content connections between accounting and taxation identified in section 3.1. The study conducted a preliminary analysis based on the compulsory accounting principles and tax rules in Vietnam and decided to remove 06 items from the survey because these contents of accounting and taxation are similar, which is based on some of the following arguments:

Fixed asset measurement: Basically, both accounting and taxation apply the historical cost principle to record the historical cost of fixed assets. The relationship between accounting and taxation is independent in some specific cases, so this content is not a general representation.

Research and development costs: In this case, taxation is based on accounting, because the record of research and development costs in accounting is more detailed than that of tax regulations as follows: Research and development costs that do not meet the criteria of intangible fixed assets are recognized immediately as production and business expenses (Ministry of Finance, 2014a).

Changes in accounting policies, accounting estimation and serious mistakes: In this case, taxation is based on accounting, because accounting clearly prescribes and instructs the principles and methods of accounting. When there are changes in accounting policies, accounting estimation and serious mistakes, which is required for the preparation and presentation of the financial statements (Ministry of Finance, 2005a), but there are no detailed instructions and regulations in taxation on this issue.

Classification of leases: In taxation, the classification of leases is not clearly regulated, so taxation relies on accounting.

Consolidation purchased goodwill: The goodwill determination is particularly regulated in accounting (Ministry of Finance, 2005b; Ministry of Finance, 2014b). However, in taxation, this content is not fully stipulated because the consolidated financial statements have not been used for tax purposes.

The scope of accounting entities and taxpayers: According to accounting, an accounting entity is an agency, organization or unit that prepares financial statements and is responsible for providing timely, complete, truthful and transparent accounting information and 
documents to organizations and individuals as prescribed by law (National Assembly, 2015). According to taxation, taxpayers are all organizations, business households, manufacturers that earn income and must pay tax.

Thus, after removing 06 items from the survey, the study focused on building a survey questionnaire based on 11 content connections between accounting and taxation in Vietnam according to Diagram 2.

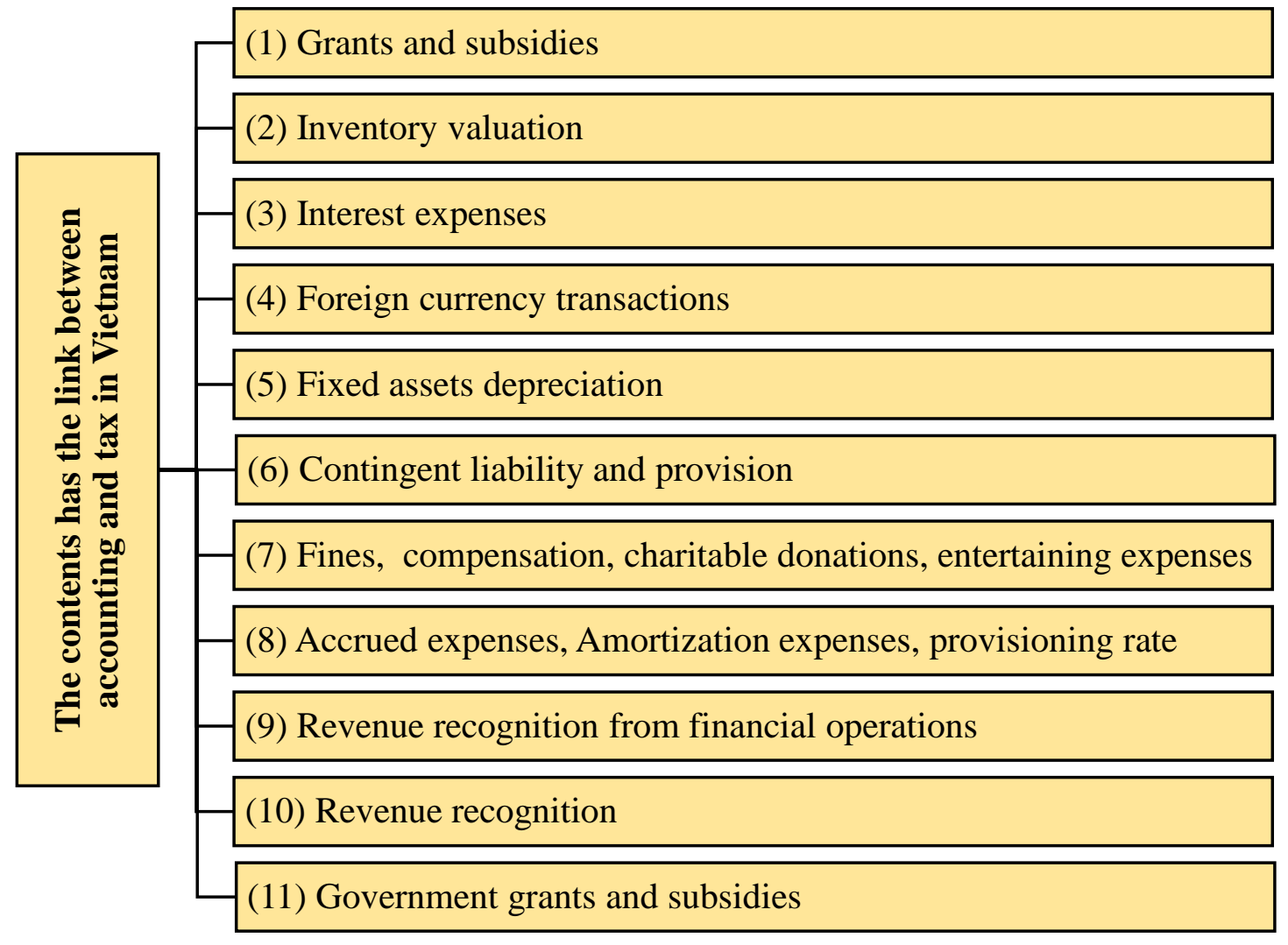

Diagram 2. The contents of the link between accounting and taxation in Vietnam Source: Author's recommendation

\section{Research Method}

\subsection{Questionnaire Design for Survey Research}

The survey questionnaire in the study was built to determine the preference for using accounting principles, tax rules or both through 6 content connections between accounting and taxation in Vietnam.

In terms of the survey structure, it consists of two parts as follows: Part A - Respondents are categorized according to professional experience and business sizes. Part B - 11 selected content connections (questions are formulated about preference for using accounting principles).

\subsection{Data Collection Methods}

The data of the study is collected through primary and secondary sources. The secondary data is collected from conference documents, seminars, topics, scientific articles... related to the research. The primary data is collected from the survey by detailed survey questionnaires 
through direct interviews or via emails or random posts to 200 accountants in different provinces of Vietnam, including: Hanoi, Hai Phong, Bac Ninh, Nam Dinh, Ha Nam, Thua Thien Hue, etc. The questionnaire is about the content connection between accounting and taxation based on 11 contents of the section 3.2. As a result, 185 questionnaires are valid, reaching the rate of $88 \%$. The survey period is from March to July 2020.

\subsection{Data Analysis Methods}

The study uses cross-table analysis to test the relationship between accounting and taxation based on the content connections. Researchers apply Chi-square. Meanwhile, comparative analysis is used to identify trends in different business types.

\section{Finding and Discussion}

\subsection{Descriptive Statistics of the Study Sample}

The collected survey results of sections A and B are presented in tables, charts and explanations related to accounting principles or tax rules or both which are selected by correspondents (the tables and charts below).

The first part of the survey consists of two general questions regarding the respondents' experience in the accounting field (Table 1) and the size of enterprises (Figure 1).

Table 1. The respondents' experience

\begin{tabular}{|l|c|c|}
\hline \multicolumn{1}{|c|}{ Experience } & Quantity & $\begin{array}{c}\text { Percentage } \\
(\%)\end{array}$ \\
\hline From $0-5$ years & 62 & 34 \\
\hline $\begin{array}{l}\text { From 5-10 } \\
\text { years }\end{array}$ & 80 & 43 \\
\hline $\begin{array}{l}\text { More than } 10 \\
\text { years }\end{array}$ & 43 & 23 \\
\hline
\end{tabular}

Source: Survey results

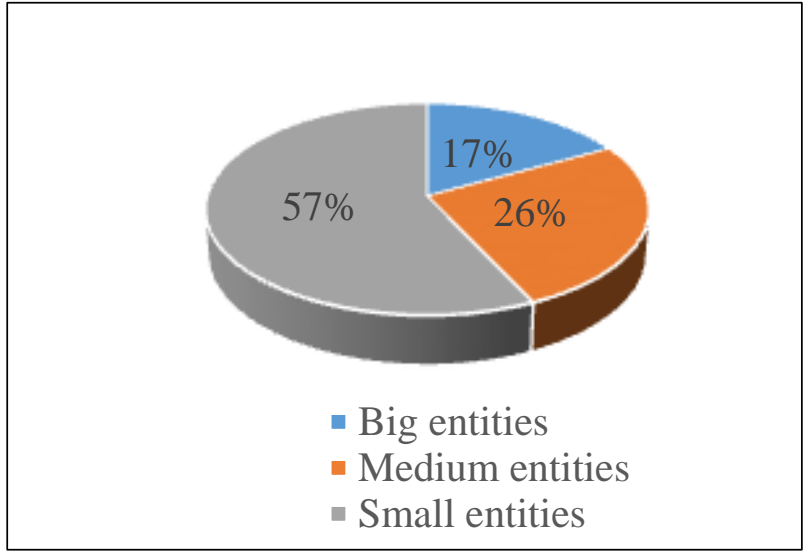

Source: Survey results

Figure 1. Size enterprises of surveyed

\subsection{Research Results and Discussion}

The next section explains the choice of using accounting principles, tax rules or both through the content intersections between accounting and taxation.

The details are presented in Figure 2. 


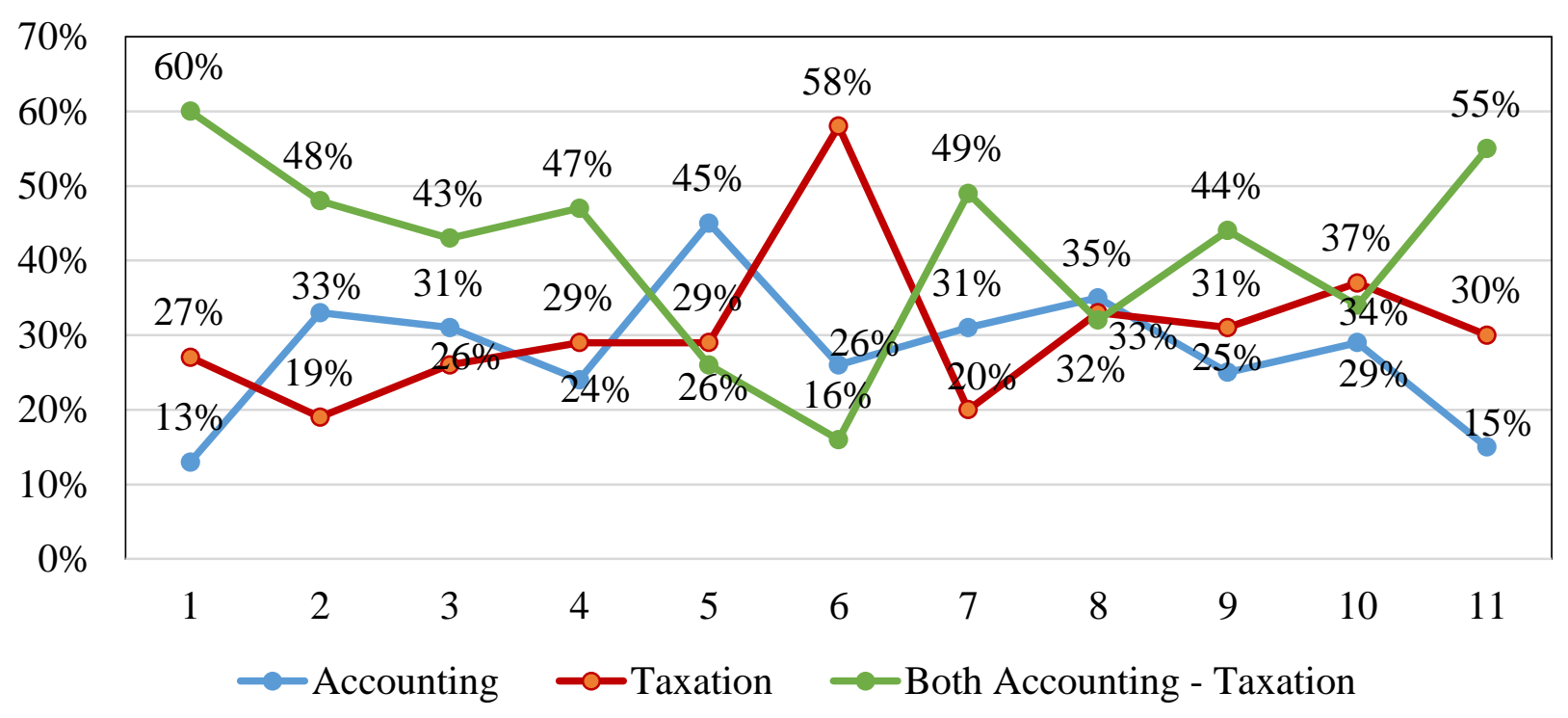

Source: Survey results

Figure 2. Survey results on the use of different rules in different contents

From the survey results illustrated above, Figure 2 shows:

(1) Grants and subsidies: In this case, the least common options is using accounting principles $(13 \%)$, the most common is using both accounting principles and tax rules $(60 \%)$.

(2) Inventory valuation: In this case, most respondents choose to use both accounting principles and tax rules (48\%), while using the accounting is $33 \%$ and tax percentage is quite low, at only $19 \%$.

(3) Interest expenses: In this case, the number of respondents using both accounting and tax rules is highest (43\%), followed by correspondents of accounting principles (31\%) and the last is correspondents of tax rules $(26 \%)$.

(4) Foreign currency transactions: This case is similar to case 3, in which the number of correspondents using both rules is highest (47\%). However, the number of people choosing accounting principles is only $24 \%$, the rest of people choosing tax rules is $29 \%$.

(5) Fixed assets depreciation: Most respondents choose the accounting method of depreciation (45\%), followed by those who use tax depreciation recognition $(29 \%)$ and the rest choose both $(26 \%)$.

(6) Contingent liability and provision: Most of the respondents use tax rules (58\%), while choosing to use accounting rules accounts for only $26 \%$. This shows that there is a significant difference; the rate of using tax rules is 2 times higher than that of using accounting principles.

(7) Fines, compensation, charitable donations, entertainment expenses: In this case, the number of people choosing to use tax rules is lowest (20\%), the number of people choosing to use both rules is highest (49\%). The rest of choosing accounting principles accounts for $31 \%$. 
(8) Accrued expenses, amortized expenses, provisioning rate: The survey data shows a relative balance among options (accounting principles, tax rules, and both).

(9) Revenue recognition from financial operations: In this case, tax users (31\%) are higher than accounting users (25\%). However, most respondents chose both rules (42\%).

(10) Revenue recognition: In the case, the survey data shows similarities among choices.

(11) Government grants and subsidies: In this case, most respondents choose both rules $(55 \%)$, tax users $(30 \%)$ are higher than accounting users $(15 \%)$.

In order to analyze and evaluate the collected data from the survey, the study conducted an overall data analysis to observe the practical situations between accounting and taxation. Through the above analysis of the survey results, we can see that there are relatively equal choices in accounting principles and tax rules. Therefore, this study focuses on combining situations related to the choice of using accounting principles, tax rules corresponding to low, medium and high levels, specifically: The (1) Grants and subsidies and (2) inventory valuation are considered low; (8) accrual expenses, amortization expenses, provisioning rate and (10) revenue recognition are considered average; (5) fixed assets depreciation and (6) contingent liabilities and provision are considered high. These results are presented in detail in Figure 3. Meanwhile, the study analyzes the survey results of 6 contents corresponding to the low, medium and high levels in order to determine the practical trends of using accounting principles, tax rules, or both rules in enterprise sizes (small, medium and large).
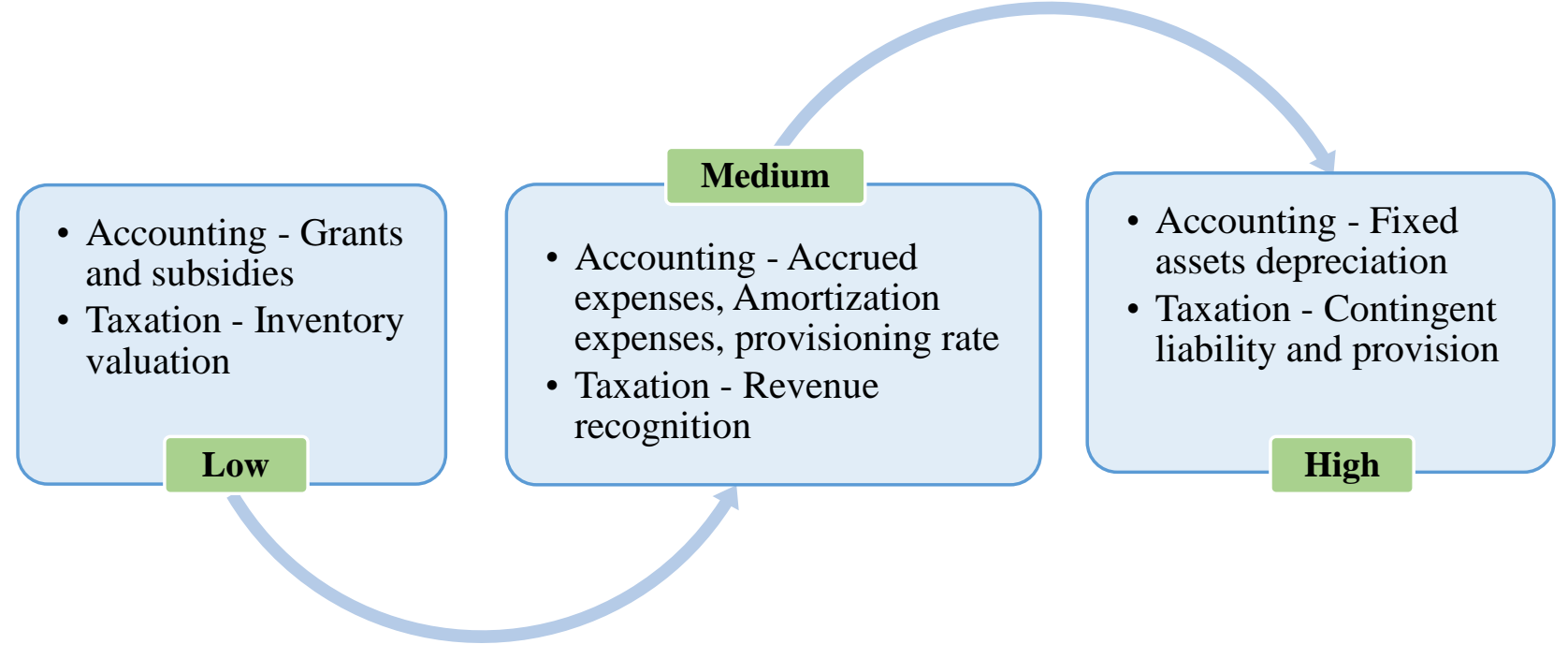

Source: Research results

Figure 3. Selection of using rules according to low, medium and high levels

Based on classification results of Figure 3, the study analyzes the relationship between accounting and taxation based on 6 contents arranged from low to high levels by analyzing the following criteria: Cross-tabulation analysis using the descriptive statistics software SPSS 20 whose data analysis results are shown in Table 2. 
Table 2. Results of cross-tabulation data analysis collected from the survey

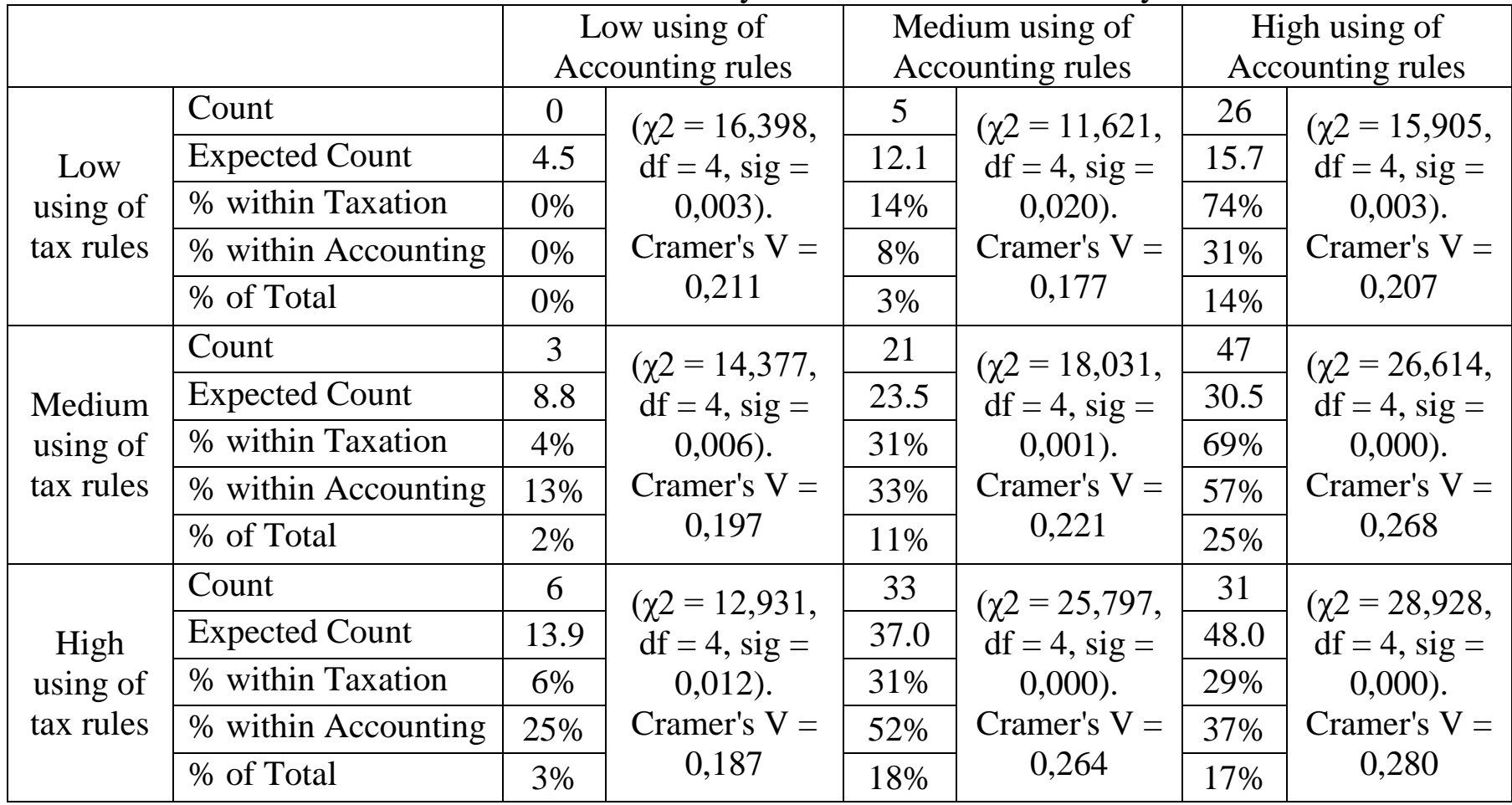

Source: Research results

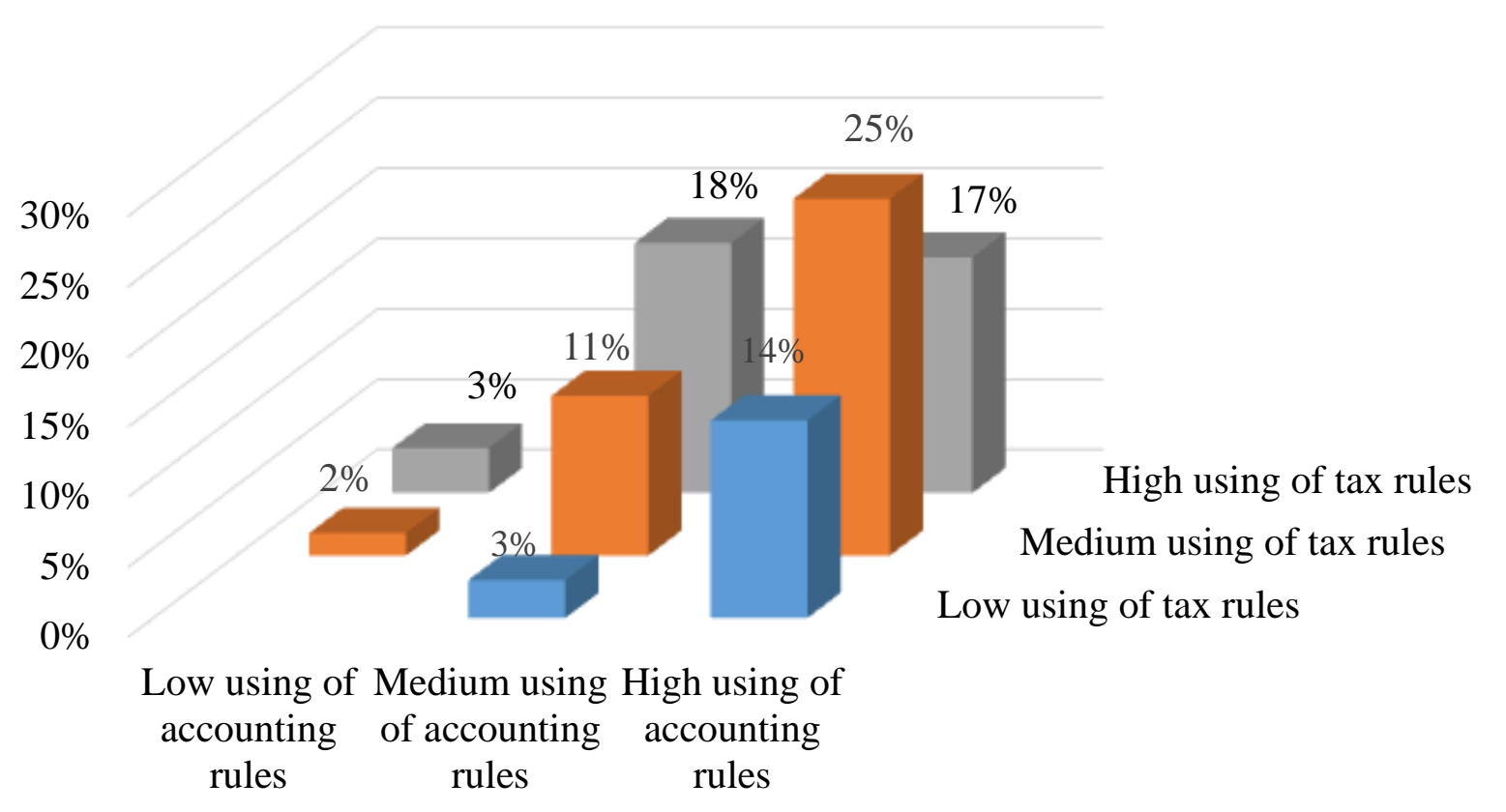

Low using of tax rules $\quad$ Medium using of tax rules $\quad$ High using of tax rules

Source: Research results

Figure 4. Selection degrees of accounting principles and tax rules 
According to the analysis results performed (Table 2), it can be seen that, there is a relationship between accounting and taxation due to the treatment difference in 6 contents (all values Sig.<0.05). However, their content connections are at different levels. At the same time, the research results show that the accounting principle selection is quite high $(56 \%)$ compared to that of tax rules (38\%) - Figure 4. This means there is a separation trend between accounting and taxation in accounting practice. In other words, the relationship between accounting and taxation has been diminished gradually because accounting is affected by taxation. This separation is arranged according to various levels (low, medium, high) and the relationship is different due to diversified contents (Grants and subsidies; Inventory valuation; Accrued expenses, amortized expenses, provisioning rate; Revenue recognition; Fixed assets depreciation; Contingent liability and provision). The distribution levels between accounting users and tax users are shown in Table 3.

Table 3. Distribution between accounting rules and tax rules

\begin{tabular}{|l|c|c|c|}
\hline & $\begin{array}{c}\text { Low using of } \\
\text { accounting rules }\end{array}$ & $\begin{array}{c}\text { Medium using of } \\
\text { accounting rules }\end{array}$ & $\begin{array}{c}\text { High using of } \\
\text { accounting rules }\end{array}$ \\
\hline Low using of tax rules & - & $3 \%$ & $14 \%$ \\
\hline Medium using of tax rules & $2 \%$ & $11 \%$ & $25 \%$ \\
\hline High using of tax rules & $3 \%$ & $18 \%$ & $17 \%$ \\
\hline
\end{tabular}

Source: Research results

The analysis results of 6 contents (according to business size) in (Table 4) show that the choices of accounting principles, tax rules and both rules are affected by business sizes (with the value Sig.< 0.05) and these selection trends are different depending on types of organizations. The results of Figure 5 explain that large-scale enterprises will prefer accounting principles to tax rules (more than 50\% of the total choices). In small and mediumsized businesses, tax rules or both rules are preferred. However, in the case of fixed asset depreciation for a small business, the use of the rules (accounting, tax and both) is quite balanced.

Table 4. Analysis results of using rules in different business sizes

\begin{tabular}{|c|c|c|c|c|c|c|}
\hline & $\begin{array}{c}\text { Grants and } \\
\text { subsidies }\end{array}$ & $\begin{array}{l}\text { Inventory } \\
\text { valuation }\end{array}$ & $\begin{array}{c}\text { Accrued } \\
\text { expenses, } \\
\text { Amortization } \\
\text { expenses, } \\
\text { provisioning } \\
\text { rate } \\
\end{array}$ & $\begin{array}{l}\text { Revenue } \\
\text { recognition }\end{array}$ & $\begin{array}{l}\text { Fixed assets } \\
\text { depreciation }\end{array}$ & $\begin{array}{c}\text { Contingent } \\
\text { liability and } \\
\text { provision }\end{array}$ \\
\hline $\begin{array}{c}\text { Size } \\
\text { entities }\end{array}$ & $\begin{array}{l}(\chi 2=62,815, \\
\mathrm{df}=4, \\
\operatorname{sig}=0,000) \\
\text { Cramer's V = } \\
0,412\end{array}$ & $\begin{array}{l}(\chi 2=12,228, \\
\mathrm{df}=4, \\
\operatorname{sig}=0,016) \\
\text { Cramer's V = } \\
0,182\end{array}$ & $\begin{array}{l}(\chi 2=20,321, \\
\mathrm{df}=4, \\
\text { sig }=0,000) \\
\text { Cramer's V }= \\
0,234\end{array}$ & $\begin{array}{l}(\chi 2=10,780, \\
\text { df }=4, \\
\text { sig }=0,029) \\
\text { Cramer's V = } \\
0,171\end{array}$ & $\begin{array}{l}(\chi 2=10,380, \\
d f=4, \\
\text { sig }=0,034) \\
\text { Cramer's V = } \\
0,167\end{array}$ & $\begin{array}{l}(\chi 2=16,111, \mathrm{df} \\
=4, \\
\text { sig }=0,003) . \\
\text { Cramer's V = } \\
0,209\end{array}$ \\
\hline
\end{tabular}

Source: Research results

Published by: 


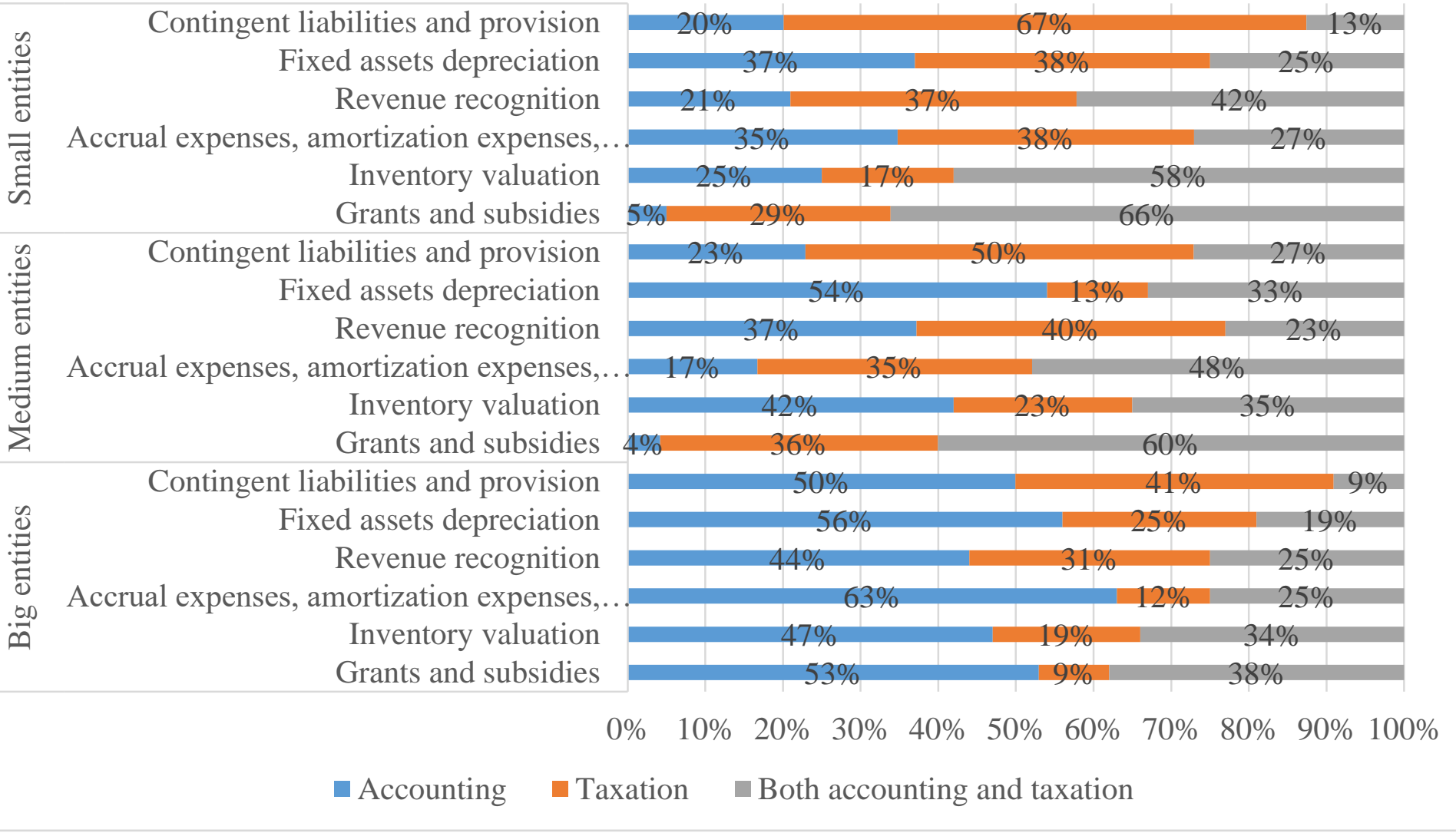

Source: Research results

Figure 5. Selection levels according to business sizes

\section{Conclusion}

Accounting and taxation are considered as two core systems of every country, so there have been quite a lot of studies focusing on the relationship between accounting and taxation recently. Basically, most of the studies show that there is always a relationship between accounting and taxation, because there is never a complete independence between them, and they influence each other. In order to demonstrate this relationship in accounting practice in Vietnam, this study focuses on analyzing 6 selected representative contents. The results show that, there is a separation between accounting and taxation in accounting practice due to the difference in accounting and tax rules. In other words, the relationship between accounting and taxation in Vietnam is gradually shifting to an independent stage, and large-scale enterprises will prefer accounting principles and vice versa for medium and small ones. However, in Vietnam, taxation exerts significant influence on accounting. In other words, taxation still dominates. Therefore, the theory and practice separations show the differences between policy enactment and implementation. Besides the obtained results, this study still has some limitations and more future studies should be carried out. In the first place, in 11 surveyed accounting issues, the research only focuses on analyzing 06 representative contents according to low - medium - high level. So the rest of contents have not been considered. Last but not least, the sample size in the study is small, so it is not representative of all enterprises. 


\section{References}

Alley, C., \& James, S. (2005). The Interface between Financial Accounting and Tax Accounting: A Summary of Current Research. Working Paper Series University of Waikato, 84.

Cuzdriorean, D. (2012). The relationship between accounting and taxation under the spectrum of the factors of influence: case study of Romania. Working paper, BabesBolyai University.

Duhanxhiu, I., \& Kapllani, V. (2012). The relationship between financial and tax accounting in Albania. Romanian Economic Journal, 15(43), 45-60.

Fekete, Sz., Cuzdriorean, D., Albu, C.N. \& Albu, N. (2012). Is indeed SMEs accounting influenced by taxation? Some empirical evidence from Romania. African Journal of Business Management, 6(6), 2318-2331.

Gallego, I. (2004). The accounting and taxation relationship in Spanish listed firms. Managerial Auditing Journal, 19(6), 796-819.

Hoogendoorn, M. N. (1996). Accounting and taxation in Europe - a comparation overview. European Accounting Review, 5, 783-794.

Lamb, M., Nobes, C., \& Robert, A. (1998). Internatinal variations in the connections between tax and financial reporting. Accounting and Business Research, 28(3), 173-188.

Ministry of Finance (2005a). Vietnamese Accounting Standards No.29 issued together with Decision No.12/2005/QD-BTC February 15, 2005 on the issuance and publication of six Vietnamese standards on accounting (Batch 4).

Ministry of Finance (2005b). Vietnamese Accounting Standards No. 18 issued together with Decision 100/2005/QD-BTC December 28, 2005 on the issuance and publication of four Vietnamese Accounting Standards (Batch 05).

Ministry of Finance (2014). Circular No.200/2014/TT-BTC December 22, 2014 on guidelines for accounting policies for enterprises.

Ministry of Finance (2014b). Circular No.78/2014/TT-BTC June 18, 2014 guiding implementation of Decree No.218/2013/ND-CP December 26, 2013 of the Government specifying and guiding implementation of the Business Tax Income Law.

National Assembly (2015). Accounting Law No.88/2015/QH13 November 20, 2015.

Nguyen Cong Phuong. (2010). The relationship between accounting and taxation in Vietnam. Economic and Development Journal, 239, 22-26.

Nobes, C. \& Schwencke, H. R. (2006). Modelling the links between tax and financial reporting: a longitudinal examination of Norway over 30 years up to IFRS adoption. European Accounting Review, 15(1), 63-87.

Shaviro, D. (2009). The Optimal Relationship Between Taxable Income and Financial Accounting Income: Analysis and a Proposal. The Georgetown Law Journal, 97, 423484. 


\section{Copyrights}

Copyright for this article is retained by the author(s), with first publication rights granted to the journal.

This is an open-access article distributed under the terms and conditions of the Creative Commons Attribution license (http://creativecommons.org/licenses/by/4.0/) 